\title{
George Herbert Mead on Ancient Greek Society: An InTRODUCTION ${ }^{1}$
}

\author{
JEAn-François Côté
}

The publication of these previously unpublished papers (in their complete version $)^{2}$ by George Herbert Mead unveils a very interesting aspect of his thought, and should attract attention because of their deep and original sociological foundations. Whereas Mead is widely known for his theoretical contribution to the development of social psychology (mainly through his posthumous book Mind, Self and Society), ${ }^{3}$ which has had a considerable influence in sociology, his own sociological conceptions have remained somewhat less known. For a number of reasons, ranging from the fact that he scattered his articles in philosophical, psychological, and sociological journals without ever assembling them into a book, to the somehow problematic legacy of his thought in the Chicago School of sociology, as well as the almost exclusive - if partial - appropriation of his views by the symbolic interactionist school, Mead's wider sociological reflections have remained virtually unexplored until recent1y. ${ }^{4}$ And even though the last part of Mind, Self and Society is devoted to "society," amounting to almost one-fourth of the total volume and pointing to many fertile developments in sociology, Mead's conceptions of society and sociological analysis per se still remain much neglected by contemporary sociology.

1. Reprinted by permission of the Special Collections Research Center, University of Chicago Library.

2. An abridged version of the first paper presented here was published under the title "The Origins of Greek Philosophy," in Carreira da Silva (2011:135-143); important sections the original manuscript (pp. 9-16, pp. 20-23) were taken out of this version and are included here. The second very short paper presented here, of which most of the original version is missing, is published for the first time.

3. Mead (1934); other important posthumous books by Mead (1932, 1936, 1938), although equally interesting, remain much less well known.

4. One can find an in-depth study of Mead's life and the career circumstances that helped delay the publication of his works in Huebner (2012). As for the lack of consideration of Mead's sociological insights in the discipline, one can turn to Habermas (1987), to see an example of how only the theory of the "self" was considered in later sociological interpretations of his work. 
While the "return to Mead" movement initiated by Hans Joas in the 1980s has been a fruitful and decisive attempt to revive the originality of this thinker, much work remains to be done if we want a more complete and clearer picture of Mead's legacy for sociological theory and sociological analysis. ${ }^{5}$ For one thing, Mead's ideas on the development of an international society, which accompanied the unparalleled development of US society during the 20th century, strike us today as acutely relevant in these times where a unilateral "globalization" has imposed itself as the new catchword to describe our world - albeit more often than not deprived, because of the strictly positive (if not positivistic) content of that notion, of its internal dialectical dynamics concerning the individual's self-consciousness and social movements which were so crucial for Mead's sociological understanding. Also, Mead's historical reflections, which shun historicism while nevertheless embracing the requirements of a scientific view of society and an historicity inspired by the logic of experimentation, can still teach us some lessons about the possible contributions a Meadian sociological analysis can provide regarding the present state of contemporary society. Mead's concept of society, in other words, still demands further attention, and much can be gained in contemporary sociological analysis from his reflections on social larger dynamics, particularly when coupled with his ideas about social reform and an "experimental path" for social action.

At any rate, and as the reader will see, the papers that follow presents Mead's main analytical claim about the relationship between individuals and society, the idea that "mind" always appears as the mediation between self-consciousness and the historical development of a specific society. For example, in addressing the development of Greek society with respect to its philosophy, Mead pays attention to the different movements that composed social relations of the times, as well as to the different spiritual and philosophical expressions that reflect them, making possible the reconstruction of highly complex social situations. The first paper situates a very important step in Mead's reflections, since it locates the origins of the scientific mind together with the social reforms that took place in ancient Greece, roughly between the 7th and 4th centuries BCE, which also witnessed the emergence of democracy

5. In addition to Joas $(1985,1993)$, in the fostering of this new interest in Mead, I will also mention the works of John D. Baldwin (1986), Gary Cook (1993), Mary Jo Deegan (2008), Filipe Carera da Silva (2008, 2011), and Dmitri N. Shalin (2011). A recent conference held at the University of Chicago, April 18-20, 2013 celebrating the 150th anniversary of Mead's birthday, gathered a number of scholars interested in renewing the research and relevance of Mead studies, and was highly intellectually stimulating in showing some of the directions in which this can be done (http://www.meadconference.com). 
as a political concept and practice. What interested Mead in this paper, then, is the demonstration of the social processes that form the basis of self-reflection, both on the part of the formation of individual consciousnesses and society as a whole, in terms of its reorganization. For him, it is the unity of these general processes - and not only the consideration of the individual and its social environment as two distinct entities - that matters. Self-reflection, for both individual and society, emerges when the old order of things fails to cope with new social conditions arising from changes within society; these changes appear at many levels (in relation to physical landscape, agriculture, craftsmanship, commerce, warfare, exchange between communities and "nations," etc.) as the basis for the innovative social reorganization required at those times, as the social fabric and institutions were reinvented and reinterpreted. The new social forms, appearing as innovations, develop to deal with the reorganization of social life and are reflected in the new conceptions that provide them with meanings, bearing both the previous contradictions and their mediations into sublated conceptual forms. Such pragmatist explanations of these situated problems, combined with their functional solutions, which Mead developed much further in his own social psychology by redefining "mind," find in this essay an exemplary sociological application. One might also have the impression that Mead, in doing so, is following a path that Max Weber opened in Economy and Society (in particular for his sociology of religion), where he paid much attention to the intersections of social practices and conceptual or spiritual formulations. If this impression proves correct, we have here the possibility of further understanding the implicit dialogue that pragmatism in general, and Mead in particular, engaged in with the Hegelian and Neo-Kantian strands of thought developing in continental Europe at the turn of the 20th century (especially with the cultural sciences and Geisteswissenschaften traditions in Germany, where Mead spent his doctoral years in the late 1880 s and early 1890 s, studying with Wilhelm Wundt, and later with Wilhelm Dilthey, among others). ${ }^{6}$

This undated paper - of which the first three pages, together with the last few, are unfortunately missing - was apparently written in the mid-1890s, intended as part of a book that was never published. ${ }^{7}$ Mead, however, taught several courses and seminars about Greek thought and Aristotelian philosophy between 1896 and 1930 at the University of Chi-

6. On this, see in particular Joas (1985: 8-19) and Cook (1993: 20-26).

7. Huebner dates the paper to 1896 , and also indicates that the book project of which it could have been part is mentioned in a letter from Mead to his brother-in-law, Henry N. Castle, in 1892 (Huebner 2012:293, note 49). 
cago, so the interest he had for the topic endured. ${ }^{8}$ Thus, this piece is not an exception within Mead's overall reflections, which also considered the Middle Ages and Modern European society, from the Renaissance to the Enlightenment and its aftermath in the 19th century - together with the annexation of Hawaii to the US in the late 1890s - and may be seen as forming a context where sociological analysis can reconstruct concrete social conditions in terms of the development of particular symbolic expressions, be they political, philosophical, or sociological. ${ }^{9}$ Selfreflection and self-reflexivity are always of that nature for Mead, and this is especially true for pragmatism, as the typical expression of US society at the time of his own writing, which he made clear in another context by naming John Dewey as "the philosopher of America." 10

The editing work done here, for the publication of the two following papers, has adhered as closely as possible, for the first one, to the carboncopy found in the Mead papers, Box 10, Folder 20, housed in a special collection at the Regenstein Library at the University of Chicago, under the title "The Origins of Greek Speculations" (a title given by archivists, based on a sentence in the text), and for the second very brief one, to the five pages left of another manuscript in the Mead papers, Box 10, Folder 33, under the title "fragment on the development of Greek political consciousness based on rational individual participation as opposed to the family or clan oriented irrational political organization of more primitive societies" (a title also given by the archivists based on the content of the text). Only typos and misspellings have been corrected; the numbers between brackets indicate the page numbers from the original typed manuscript. We wish to thank the Regenstein Library of the University of Chicago, and especially Daniel Meyer, Director of Special Collections Research Center, for granting the Canadian Journal of Sociology permission to publish these two papers.

\section{REFERENCES}

Baldwin, John D. 1986. George Herbert Mead. A Unifying Theory for Sociology. Newbury Park, CA: Sage Publications.

8. On Mead's teachings, see the Appendix 1 in Lewis and Smith (1980:262-271).

9. About his courses on the Middle Ages, see Lewis and Smith (1980); on modern European society, see the posthumous book by Mead (1936); on Hawaii, see the analysis provided by Huebner (2012:72-77).

10. G.H. Mead, "The philosophy of Royce, James and Dewey in their American setting," originally published in the International Journal of Ethics XL (1929-1930:211-231), reprinted in Reck (1964:371-391, citation p. 391), and also available, as all of published Mead articles, on the website of the Mead Project located at Brock University (http://www.brocku.ca/MeadProject/inventory5.html\#sectM). 
Carreira da Silva, Filipe. 2011. G.H. Mead: A Reader. London: Routledge. 2008. Mead and Modernity. Science, Selfhood and Democratic Politics. Lanham, MD: Lexington Books.

Cook, Gary A. 1993. George Herbert Mead: The Making of a Social Pragmatist. Urbana: University of Illinois Press.

Deegan, Mary Jo. 2008. Self, War \& Society: George Herbert Mead's Macrosociology, New Brunswick, NJ: Transaction Publishers.

Habermas, Jürgen. 1987. Theory of Communicative Action, vol. 2. Boston: Beacon Press.

Huebner, Daniel Robert. 2012. The Making of George Herbert Mead: A Study in the Production of Knowledge in Modern Academia. Chicago: Ph.D. Thesis. University of Chicago.

Joas, Hans. 1985. George Herbert Mead. A Re-Examination of his Thought. Cambridge, MA: MIT Press.

1993. Pragmatism and Social Theory. Chicago: University of Chicago Press.

Lewis, David J. and Richard L. Smith. 1980. American Sociology and Pragmatism: Mead, Chicago Sociology and Symbolic Interaction. Chicago: University of Chicago Press.

Mead, George Herbert. 1932. The Philosophy of the Present. Chicago: Open Court Publishing Company.

1934. Mind, Self and Society. Chicago: University of Chicago Press.

1936. Movements of Thought in the Nineteenth Century. Chicago: University of Chicago Press.

1938. The Philosophy of the Act. Chicago: University of Chicago Press.

Reck, Andrew J., ed. 1964. Selected Writings: George Herbert Mead. Indianapolis: Bobb-Merrills Co.

Shalin, Dmitri N. 2011. Pragmatism and Democracy: Studies in History, Social Theory and Progressive Politics. New Brunswick, NJ: Transaction Publishers. 


\section{George Herbert Mead, “On the Beginnings of Greek Speculation"}

(Box 10, Folder 20, PP. 4-33)

[4] It is evident that if this chasm is to be bridged the control which is the most essential element in attention can be placed neither in the environment nor yet in the individual as distinguished from each other. To do the first destroys the personality of the thinker and to do the other places [is] quite outside the development that we are trying to trace.

We can state this psychologically by saying that the control cannot be lodged in the object as stimulus, for the object that calls forth the action which follows from the state of attention is the outcome of the state of attention. In the state of attention the outer objects lose their objective value in so far as they bear upon the action that is to follow. The person giving attention to the obstacles in front of him in the endeavor to find a path that is not as yet evident, finds in the things about him no objective validity so far as the yet undiscovered path is concerned. They present to him only subjective indications of what this path may be. The whole locality must be reconstructed and no one of the things there so far as they have had validity in the past can control his action. The past meaning cannot direct him at present. Out of the reconstruction arises a stimulus that assumes control of his act, but so far as his perception is concerned it has not been there before. The control cannot then be placed in the objective world for this leaves out the psychological individual whose activity lies between the old world of experience which is inadequate to direct his present act and the reconstructed world which now [5] presents the adequate stimulus, just as the historical method which puts the control in the environment leaves out the personality that it is trying to explain.

It is equally impossible psychologically to put the control in the psychological individual as distinguished from its objective world. In such an individual there cannot be present the consciousness of what he is about to do [-] i.e. of the path that he is to follow [-] or he would not have to hunt for it. The process goes on within him and he has a most vivid consciousness of the process in its separate stages. But his consciousness before the act is nothing but the sum total of his past 
experience which is confessedly inadequate to the present emergency. But this past experience in the form that it exists before this emergency arises represents the only possible control that he could possibly exercise over any following act. A psychological individual that could control, then, the process of attention in which the world is reconstructed would have to exist quite independently of the experience which must make up the whole content of his experience; just as the historical method which lodges the control in the individual must for time make him independent of the past out of which he arises. The one method annihilates the individual in whom the reconstruction takes place while the other isolates him completely from the whole of experience of which he is yet a part.

There is only one escape from this dilemma. We must postulate the act as a reality within which the outer world[,] i.e. the past [6] of experience so far as its meaning for us is concerned, and the process of reconstruction as taking place within the individual both lie as successive moments. To return to the former illustration[:] the formalism of the "Enlightenment" period[,] the English psychology and the French social theory form the objective world of thought out of which immediate reaction must follow for Kant or any other thinker. Kant's consciousness is the recognition of the inadequacy of these stimuli for further advance and the reconstruction of the world so that it may be a stimulus to adequate thought. In other words[,] the history of consciousness can neither put the world of experience outside the consciousness of the individual nor can it [put] consciousness of the individual outside the world of experience. They must both in their immediate value find their places in the development of which they are but separate moments.

A legitimate method for the history of thought must then first of all determine the movement which any period represents and then find the place of thinkers whose systems it studies in that movement - not treat their systems as independent reactions upon the forces represented in this movement but as moments within that movement.

There are two methods of presenting the history of philosophy since that science arose. The one follows the method sug[g]ested inadequately and the other which aims to present the contents of the systems studied as psychical reactions upon the conditions of their time more or less illustrated and interpreted by a statement of these conditions.

[7] The great representative of the former is Hegel. The inadequacy of his work lay in his inability to state concretely the great social movements within which the philosophic systems fell as separate moments. It is but fair to him however to recognize that this inability was rather an expression of the infancy of [the] science of history than of his unwillingness to recognize the fullness of concrete detail that makes up 
the development of consciousness. There are no lack of representatives of the second class. They vary in their value all the way from Lewes to Zeller and Windelband. It is characteristic of all their statements however that they so isolate the consciousness of the different philosophers from the movement of which they were a part that they practically place themselves in the place of these thinkers with a varying appreciation of conditions under which they lived. Now such a statement if carried out consistently gives an aesthetic rather [than] a scientific result. An aesthetic view of the past is that which reproduces it within ourselves with the valuation which our own feelings set upon it. It inevitably follows that the criterion of consistency and adequacy of the statement must lie in our own emotional valuation attuned to conditions under which we live. As examples we may offer the anachronisms of Jovett's English gentleman in the Platonic Academy or Zeller's German philosopher in the Schools of Miletus or Abdera.

It is the purpose of this paper to suggest the lines along which an adequate account may be given of the beginnings of Greek speculation.

[8] The life of the Greek race has been determined as has been early recognized by the physical character of their country. It broke them up into small communities largely situated upon the sea-coast with but slight possibility of spreading inland. The land itself except a few localities was not capable of supporting a large population even from the standpoint of the relatively small communities that inhabited them. It followed that the natural increase in population flowed out almost constantly except in later periods of Greek history over the sea in small contingents. There were three circumstances that made these overflows the determining feature in Greek history[:] the intermediate position of Greece between the east and the west, the contact with the old civilizations of the $[\mathrm{O}]$ rient and the easy succession of the Greeks to the commerce and factories of the Phoenicians.

So far as outer counties were concerned[,] Greece had all the advantage $[-]$ indeed a greater advantage than her inlands. In the periods of her earlier development[,] she could not be approached except from the sea, and it was an easy task for her to maintain even recognizing the smallness of her separate communities a naval superiority over the land empires of Asia Minor and Egypt. Greece came therefore into contact with the civilizations of the east with no danger of being absorbed herself. Her relationship was therefore preeminently one of commerce. This made her familiar with the products[,] and following from these the technique of these societies[,] without entering into their political [9] [and] social conditions. This relationship was of great importance in the evolution of the Greek thought. She succeeded to the technique[s] of other 
nations but not under the conditions which kept them mere techniques. She was at liberty to generalize upon the activities of other peoples without the fixed habits which belong to arts acquired in the struggle for existence. The Greeks without doubt had minds peculiarly adapted to generalization but that they had in this circumstance a strong stimulus to the process cannot be denied especially when we see how they took up the mass of practical acquirements in land-measuring from the Egyptians and of astrological observation from the Assyrians and built up upon them the science of Geometry and Astronomy.

On the other hand the Greeks found in paths and factories of the Phoenician merchants not only a commerce ready to their hand in which the[y] easily outstripped their competitors but the places already marked out for their colonies. Their greates[t] superiority [towards] the Phoenicians lay in the fact that the mother country was steadily pouring out swarms which could locate and defend their points of commercial contact with other tribes, while the Phoenicians never had a population which was beyond the requirements of the home life and the trade which they drove on [the]coasts of the $[\mathrm{M}]$ editerranean. That the Phoenicians were no mean competitors for the Greeks in war as well as in organized commerce when they were able to establish fixed colonies[,] the rise of Carthage and the vigor and promptness with which she shut the Greeks out of her territory in the western part of the Mediterranean show most vividly.

[10] It is comparatively easy to see also in the conditions of life in the earliest Greek communities the meaning of her political institutions. When their hordes came down from the north at the time of first immigration they were obliged to break up into small bodies answering to the broken character of the landscape. They in all probability consisted in those first communities of bands of nearly politically equal warriors who corresponded later to the citizens of later periods. The headship of these bands of warriors lay with personally powerful leaders who passed over into the Kings of the Homeric times. But the minuteness of the separate political bodies never allowed these to gain the overwhelming predominance of the oriental monarchs. Such a predominance answers on the one side to the vastness of the communities they represented and on the other to the helplessness politically of the mass of the people over against the isolation which spatial separation and rudeness of all social conditions in barbaric and semi-barbaric times. The Greek kings had therefore neither the mass of great communities behind them nor did the necessity of setting up and maintaining over a wide-spread community by sheer brute force thrust into their hands absolute political power. It followed from this situation that the king fell with hardly a struggle before growing 
landholding nobility: for the control which the latter exercised in the management [of] farms and herds and in their possession of capital made them a governing class of vastly more importance than the hereditary military leader. [11] And in general the smallness of the Greek community made those in whose hands the industrial control lay politically the most important in all the stages of industrial development. It was impossible for the conception of an abstract political authority to strike deep root in Greek soil. The people were from the first too conscious of the political value of the immediate industrial and social activities to submit blindly [to] arbitrarily political power.

There is no sufficient evidence to show that the Greeks in their first immigration regularly subjected the former population as serfs and lived upon their labor. The passage of the people from a nomadic conquering horde living from plunder and their herds to communities fixed to and dependent on the products of the soil made a small farmer out of the former free warrior with but little politically subject[ed] labor. It was the advantage of farming and herding on a large scale on the one side and the leisure for exercise in arms on the other that gave the larger land-owners their power and built up the Greek nobility. That a feudal system did not spring up out [of] these conditions was largely due to three causes. In the first place the broken character of the landscape made fighting from horseback of little importance in Greek warfare. Even when the noble warrior went to the battle in a chariot or [on] a horse the advantage was largely that of bringing him fresh and unwearied into the contest. In the second place advance in scientific warfare soon made the compact body of common soldiers far superior to the individual fighter however well trained and fresh for the battle.

[12] In the third place the $h[e]$ ights in the Greek landscape do not command the plains[;] they protect them so that there was neither the temptation to the nobles to build strong-holds to hold in check a subject[ed] population nor if [built] would they have been of any importance in defense against the outer enemy. The line of defense was at the border not in the center. The city wall was in my opinion much more a defense against forces which later came by sea. In Sparta[,] Arcadia[,] Thessaly and $\mathrm{Ph}$ [oeni]cia the city wall was never built or arose only much later. But whether this was true or not the conditions under which the cities arose were absolutely different from those under which a feudal system could have sprung up. It was the very conditions of Greek life based upon the character of the landscape that kept the nobles from gaining a lasting political predominance through their superiority in war.

The formation of the city out of the village farming communities was the direct result of the entrance of trade and the consequent industry. It 
was a process that had commenced even in Homeric time. The nobleman went then to the city to provide himself with iron and tools and other necessities.

The Phoenician trader brought on the one hand the commercial center to the neighborhood of the coast and the frequency of piratic descents (for trade and piracy went hand in hand) made a walled place of defence a necessity. The packing of these early cities is represented as one of the chief sources of income of the Homeric king. But the movement became more definite and grew with increasing force as the character of the communities became more and more industrial[...]. Out of this [13] movement grew up a distinction between the city and land population that was for the time of increasing disadvantage to the small landed farmer and the day laborer. Only the wealthy could afford at first to live in the city and he only therefore was able to be present at the political gatherings. The noblemen therefore increased the importance of their positions.

But a still more important influence in the same direction though it ultimately led to their fall was the introduction of money with the advantage to the capitalists which arose from the first appearance of currency. Money was of prime importance to growing trade and commerce of the country and was therefore in great demand. As the chief source of income [...] still from the landed estates it is probable that the land-owners demanded their rents in this so far as possible and the difficulty of obtaining it drove the tenants into debt that redounded to the advantage again of capitalist[s]. High rates of interest were the natural result and there resulted the growing indebtedness of the small farmer and tenant which under the severe laws of the time carried an enormous number of them over into slavery or at least absolute dependence upon the increasingly wealthy nobles. The foreign slave was more easily managed than the native and the tendency was to substitute these for the home laborer and to sell out of the country those who had become such from debt. But side by side with the old populations had grown up a new trading and industrial class - a middle class, who for the time being accepted their [14] subordination to the nobles but who became the center of rising discontent. In some of the communities such as that of Corinth the nobility itself gradually changed from a landed to a commercial body, and there for a century and a half directed Corinth's commerce and her colonization. In the Colonies [sic] of Asia Minor this was in many communities the case. For here much earlier than on home mainland the change from husbandry to industry and commerce as the chief source of activity took place. But for this great task of reorganization of the community the nobility proved itself in the main inadequate. This reorganization was in the nature of this case a reorganization of the entire Greek community 
not of unconnected cities. The center of interest could not be transformed from the culture of the land to that of productive arts and of commerce without a complete change of basis of the whole society. It seems to me that this change is very clearly indicated in the movements of the Greek population. There are only two ways in which surplus of population over producing power of the land can be met[;] either it must flow out in conquering migrating tribes, or in smaller colonizing bands, or again under favorable circumstances as mercenaries to foreign wars; or else the productive power of the country must be increased directly by more intense agriculture[,] a process of which we have some indications in the remains of manuals of scientific farming, or indirectly by the production of articles which may be exchanged for food products that are brought from a distance.

[15]We find indeed that colonization from the Greek mainland continued in general till the favorable localities along the coast of the Mediterranean had been occupied or the Greeks had been shut out from further extension by the Persians on the east and the Carthaginians on the west. From this time on there was but one possibility of further natural expansion for the Greeks — that [is] through industry and commerce. That this possibility was open to them was due to the opening up of two great regions of the export of grain — in the north from the Thracian coast and the Hellspont and Propontis and those of [the] Black Sea[,] and in the west from Sicily and lower part of Italy. From this time on further development in Greece depended upon the organization of a commercial community including the colonies and the mother communities. This relation was of course set up much earlier in the case of such cities as those [of] Corinth and Aegina whose limited and unproductive soil was from the first unable to carry any large population and whose favorable position for commerce made them very early centers for first a carrying and then an export trade. The same process took place at an earlier date among the colonies of Asia Minor especial[1]y the Ionians. These were shut of[f] from the mainland by continual warfare with Asian communities and their positions on headlands and bordering islands. Their trade with the mainland was largely in articles of luxury and utensils but the $[y]$ were forced to provide themselves with grain from the Hellespont and the Propontis. Miletus had over seventy[-]five of those colonies [16] whose chief function must have been to provide her with the necessary food for a home population that was far in [ex]cess of what their own soil could support. Sparta early adopted a policy which was indeed conditioned by the new Greek community but which placed her in a large measure outside [of] it as far as her internal development was concerned. She gained control of a rich territory in the valley of the Eurotas and in 
Messenia which gave her food enough for her citizens-warriors while she gained and maintained a political control of the commercial communities that lined the coasts of the Peloponessus. They were essential to her for the import of utensils of war, agriculture and the house-economy[.] Athens on the other hand was forced by the poverty of her soil to base her political supremacy upon her commercial life. She was invi[nc] ible as long as she maintained this policy. When however she substituted a policy of exploiting her dependencies instead of maintaining the natural commercial and political hegemony[,] she lost her superiority. The responsibility for this is however to be laid at the doors of Greek commerce itself [-] which as we shall have occasion to see later was in its very nature an exploitation. One characteristic feature of ancient life remains to be noticed, that of slavery. The introduction of manufacturing industry meant for this period the large importation of slaves, in other words a swelling of the population far beyond the natural increase and a $\mathrm{h}[\mathrm{e}]$ ightened dependence upon the outer sources of food supply.

[17] The process of reorganization took place in the time of the tyrants. Later historians of Greece have commenced to do justice to the important work which the tyrants accomplished. The cruelty and arbitrary personal injustice and injury of which we read so constantly were but the expressions of the semi-barbaric conditions of the times and the savage strife that they were forced to carry on against the nobles.[...] On the other hand we find that they earned the support of the mass of the population in very many instances and almost universally undertook and carried out public works of great importance to the health and development of their communities and immensely widened the commerce and trade relations abroad and built up industries at home. The nobles proved utterly unable to grasp the new situation[.] They were too much engrossed in their local ambitions and the pursuits of individual success and pleasure which did not look beyond the old community to be able to stimulate the trade and industry which were essential to further growth. The tyrants represented[,] on the one hand[,] the small farmers and day laborers whom the new commercial relations had reduced to extreme misery[,] and on the other[,] the new industrial population that was springing up in the cities. What the tyrants of Corinth[,] of Athens or of Syracuse accomplished was as essential to the development of Greece as the achievements of her great law-givers.

It is to the period of this great reorganization to which the earliest Greek philosophy belongs. It took place first in the colonies and it [is] there that we first meet Greek philosophers. [18] What took the place of a conscious philosophic construction of the world for the mass of the people and for all before this period was the religious. In Ionia this 
was generally the Homeric cosmology and theology. As contrasted with the Hesiodic and the somewhat later Orphic cosmogonies and theologies that developed on the Greek mainland princip[al]ly[,] it was preeminently social in its motive. It was not the origin of the world that so much interested the Ionians as the immediate human relations that were the expression of their highly social communities. In these wealthy cities the struggle for existence of the small farmer[,] which is so vividly portrayed in Hesiod[,] did not come to expression[,] with the consequent endeavor to generalize their local cults and conditions in a statement that would give them the religious value of their struggles. The Homeric songs were literature of the wealthy families who heard in them the praise of the prowess of their ancestors. For the Greek mainland Homer was purely romantic. For Ionia the poems answered to social conditions near at hand and carried with them a sense of reality that [they] could not have in Greece proper. On the other hand the antique cosmogony of the Homeric left the world that was constantly widening without adequate explanation.

It is this difference that is most marked in the intellectual developments of the two societies. In Greece proper the explanation of the physical world and its origin is undertaken from the standpoint of the generalized local cults under the influence [of] religious need. In Iona the religious tradition at this period was still quite objective and was exhausted in the statement of [19] the social relations of the older period. Ionia was then thrown back upon the older animism to account for the outer world so far as this [question] demanded in the new discoveries in the west and the north became the subject of speculation. The influence of these voyages into the far north and especially in the far west [was] of the greatest importance not only in the commercial growth of the people but also in the intellectual life that depended upon it. The daring triremes of Phokaea had gone even beyond the pillars of Hercules [...] had set trade relations with Tartessus[,] had founded the colony of Massilia at the mouth of the Rhone and had connections with the Sardinia and the modern Elba. The widening of the outlook that followed from these voyages must have been comparatively as great if not greater than that $[\ldots]$ which expanded the world of Europe in the voyages of Columbus and his successors. For the statement of this new world the Greeks of Ionia had nothing to fall back upon except the animism which underlay the older mythology. The Homeric gods located upon Olympus could not easily be brought into the relationship with the almost infinitely distant west and north. They had been fixed in types of the social relations corresponding to an older social order and [t]here was nothing in their very human character which admitted of the physical expansion 
that marked this period. It is this condition that finds its expression in the living but impersonal substances of the Ionian philosophy. The attitude so far as it ascribed life to all things was [20] the naive view of all peoples out of which mythology grows but what calls for explanation is that the Ionians should in a certain sense have reverted to it after the animistic stage had been passed in the growth of the Greek theology. It is not difficult to give. The personalities that are represented in Homer are too socially fixed and defined to be made the carriers of the new world that had opened before them. So far as this came clearly to consciousness there resulted a necessary conflict between the two views of the world[;] instead of the deepening of the older religious conceptions that is found in the cosmologies across the Aegean we find a scientific criticism of the mythology such as is best represented in Xenophanes.

There is another large element in the problem that so far as I know has never been adequately recognized. This is [the] character of Greek commerce.

There were three general classes of articles in which this dealt[.] In luxuries[,] utensils especially of metal and pottery[,] and food products [-] especially grain and olive oil. In the period to which we now refer - the seventh and sixth centuries [-] the household of the average Greek was pretty independent. Spinning and weaving were done at home[,] the few necessary utensils and tools were easily made either at home or among those in the immediate vicinity and the interchange was largely on the principle of the barter. The result was that the values of the articles could not be reduced nearly enough to the actual expense in human effort so that trade could bring to consciousness the social relations which it involves. [21] But this was not only true in the trade between the advanced commercial cities and the more primitive communities but equally so in the interchange between so distinct civilizations as that of the [O]rient [and] the simpler civilization of Greece. It was preeminently true of the relations of the Greek merchants to the barbaric tribes with which they largely dealt. Trade was in a large degree with the Greeks an exploitation[.] It was so conceived by them at all times. As Aristotle expres[s]es it ["]trade for the sake of making money["] is contrary to nature and enriches one party at the expense of the other.

The result of this on the one side was that the physical means of commerce and the obstacles overcome were divorced from any controlling social valuation. They remained purely physical [-] not as so much dead matter but in the period referred to[,] outside human relations. On the other hand the peoples with which the Greeks dealt were not by their commercial relations made a part of their society. They were the barbarians who were to [be] exploited abroad and enslaved if brought among 
themselves. They represented also so many physical obstacles to be overcome of only negative value in their lives. In general then the character of the Greek commerce tended to abstract the means which they used from the social end which they served. The end pursued and gained was purely individual - the wealth of the citizen or the community. Piracy and trade stood upon the same basis with the earlier Greeks and the suppression of it was motivated by the necessities of particular cities or friendly combinations. It was impossible to spiritualize these means get their full social value - from the standpoint of the individual alone for [22] his success or that of the single state did not involve the whole of the means. It is the obverse side of this upon which Plato and Aristotle lay so much stress asserting that money-getting had no natural limit leading up simply to the inexhaustible individual desires.

In a word one cannot follow a partial end without abstracting the means and setting them off as an independent entity. It is only when the means are completely expressed in the end that they can disappear as an independent existence, the goal Aristotle set for his statement of the world. In the cults especially on the Greek mainland we have a statement of the whole paraphernalia of the means necessary for the primitive life of the community in terms of the end personified in the divinity whose function is social [-] i.e. includes the whole community. The generalization of these in the Hesiodic and Orphic cosmogonies retains this characteristic. The whole world is still spiritual. For they are built up on the fundamental processes of agriculture upon which the Greek community rested. It is the use of a vast extent of means which cannot be expressed in the social life of the community that leads to the dualism that finds its most complete statement in Anaxagoras. This is involved in that to which we have already referred - the inability of the Ionians to so extend and deepen their theology as [to] make it a carrier of the wide commercial life they had entered upon. We can express this in other terms by saying that the commerce of the Greeks never became a healthful integral part of their society. At the end of the period of Greek political development both Plato and Aristotle [23] look upon commerce as non-social[,] to be relegated to those who are not citizens. In the nature of the case it could never have become social in the true sense except by taking in those who were traded with into the same society. If this had been done the Greeks would have deified the means by which commerce was carried on as they did all that carried out truly social ends. As it was they had upon their hands a whole new world of physical means which in the nature of the case soon overbalanced the feeling for the social character of the end. In Xenophanes and Parmenides we find the mere assertion of a unity in which the relation of 
means to end is entirely lost. It is physical world without differentiation. Leucippos and Democritus finally differentiate out of it the pure means as such and in this form it has remained the expression of the abstracted means over against the abstracted individual up to our own time. But this latter development involved the differentiation of the abstract individual as such which came only later. It was Pythagoras who carried to the west the profounder feeling for personality which had [impacted] upon the Hesiodic and Orphic movement. These movements had as the chief moment the recognition of the deity in the individual. But it was not the deity of the Homeric theology. It was [the] enlarged conception of the divine which corresponded to [the] fusing of the local cults of the separate clans that had been welded into single communities such as Athens or Thebes, to the coming to consciousness of the mass of the people over against the traditional gentile divisions at the head of [24] which stood the nobles, to feeling of the race unity with its representation at Delphi. It carried with it a host of crudities that betrayed its source in the local cult but it was the feeling of the larger social unity which could only arise in the mother country where there was a massive population that could come to consciousness of itself as a whole over against the barbarians without losing the sense of their unity in the multitude of commercial and political relations which filled the consciousness of the Ionians. It was the new Greek individual that went to the west in the Pythagorean movement at much the same time that Xenophanes carried to the same locality the conception of an objective world of being independent of human consciousness. It was an individual that felt its roots deep in the past and looked to a future of full self-realization, that took up into itself the consciousness of the past history of the race and felt within itself the divinity ordering its future growth. To bring this individual to consciousness and to so order the life in accordance within a divine harmony that it should become dominant and advance to full realization was the aim of the Pythagorean way of life. Empedocles expressed these two trends of thought in strange juxtaposition. On the one side[,] there is the scientific explanation of the objective world[,] and on the other an ecstatic realization of a profound personality. But the ecstasy disappears [as] the way of life loses its religious enthusiasm and there arises out of the endless city feuds that shattered this sense of the race-individual the abstract political unit [25] carried back from the west to the east by the sophists. Anaxagoras puts for the first time the two principles over against each other, in their abstract statement, while the Atomists take advantage of the standpoint of a purely abstract intelligence to develop the complementary conception of the purely abstract world of means. 
We have then a series of reactions of the eastern colonies upon the mother country and Greater Greece in the west, of the Greek mainland upon the cast and back again upon the west and finally of the west upon the mother country again. And this corresponds to the great movement of Greek history. As we have seen her problem was that of expansion. First her surplus population flowed out in the early colonies and took up the commerce of the Phoenicians they drove out. Clinging to the edges of hostile territory it was only by commerce they could live and they felt their way to the grain fields of the north on whose products they could live while they traded and fought with their neighbors. In the meantime in Euboca[,] Corinth and Aegina there had sprung up other commercial and especially colonizing powers with their western connections. It was in the political and commercial readjustments that arose at this time of conflict with forces within and without that the Greeks of the east first came to consciousness. It was in this readjustment especially toward the west that what had been a world of objective stimuli became for the time being but subjective indications of a great process that was going on without them in which they must find their place. Thales [26] and his successors can be but examples of what was [a] less explicit form taking place among the fellow citizens. The necessity of adapting themselves to powers extending themselves into the far west toward which they had not thought of turning their galleys, must have expressed itself in an act of attention in which the whole outer world with it's [sic] former values and meanings vanished. The west no longer ended with Kerkyra beyond which could be located the hobgoblins of Greek mythology or the Happy Isles. As such it had disappeared and as yet there were present in consciousness only the formed habits of navigation and trade in known waters. These could however respond only to elements in the new world which had not been felt as a part of it before. Until the new object was formed these elements would have only subjective value. In other words[,] there stretched out before the Ionians a vast expanse of water that was not the sea they knew and yet could be only stated in terms of their past experience until they had reacted upon it and had [became] familiar with it. For a practical nature this phase has no interest in itself[,] for the speculative mind it becomes center of interest, but what needs to be noted is that there is and can be no qualitative difference between the attitude of the man of action facing the same world under the[se] conditions and that of the philosopher. The shipmaster who stood before unknown waters of the west was forced to state them in terms of indications out of past experience that needed only amplification to become a world theory. Thales [27] simply represents the essentially theoretical attitude of his times. But this disappearance of the objective value 
of the stimulus could not at first be interpreted as the substitution of a psychical state for an outer object. Such an interpretation would have involved the recognition of an individual abstracted from an environment, which as has been indicated did not arise till the time of the sophists. For the Greeks of this period the outer object disappeared under their fingers to be replaced by a generalization out of past experience which was still necessarily as objective as the former object. It differed from the former object only in not being a stimulus to action but to further reconstruction. The Greeks in their naive period had noticed the changes in which what was before their eyes disappeared and was succeeded by other objects. But as long as an object remained individually intact and was simply replaced by another object equally defined there was no possibility of the conception of an underlying substance different from the objects assuming successive forms. This could only come when such a process of analysis as that we have sketched had robbed the object of its fixed form and yet had left behind the recognition of a reality which was undergoing restatement. The imagination in the child or in the naive period of race development delights in the substitution of one object for another even with the assertion of the same social content and value as in the change of gods or men into animals or [28] plants. But this is the substitution of one object for another with the maintenance of the same social relations and contents. It is not the analysis of the object into a something else that can appear in different forms. Such an analysis only takes place when attention holds in consciousness the elements of an object which has lost its objective value for us. Without such an analysis the object that is gone is necessarily replaced by the new object which fills the field of vision. Our sense of continuity may retain its social identity, but this is in no sense the scientific conception of the transformation of form while the object remains unchanged. Now the disappearance of the mythologically constructed world and the continued presence in attentive consciousness of the generic elements of a vast expanse of water surrounding a limited continent is the first recorded instance of such an analysis. On the Greek mainland in the great cosmogonies no such analysis took place. One object succeeded another. Only the social content was deepened[,] widened and yet individualized. And such an analysis for a consciousness that was yet purely objective must have substituted the more generalised [sic] elements of past experience which remained after the dissolution of the object as the ultimate reality of which the former object was only a phase. And furthermore these Greeks must have just as inevitably have assumed an objective process for this change. It is the recognition of this which we have in the Arche (the beginning) of the Milesian school. It stamps their systems as scientific as distinct from 
[the] mythological. What particular process they should have hit upon as the carrier [29] for this analysis is a matter of little importance as far as the nature of the activity is concerned. It was seemingly natural that the ever present meteorological changes should have been taken. But the value of Heraclitus' profound grasp of this phase of our consciousness does not lie in the identification of the changes with fire[,] water[,] air and earth but in [the] thoroughgoing recognition that no object can possibly remain in consciousness unchanged. Panta rhei [Everything flows]. Here again [...] we have but the vivid recognition and explicit statement of phase of the common consciousness of the time. It probably found its popular expression in an animism which simply said that the world lives and passes through the changes of life. At least we find this conception entering in Anaximines[,] potent in Anaximander[,] but most naively stated in Pythagoras who stood much nearer the popular consciousness than the Milesians.

The Persians on the east and the Carthagenians on the west effectually put a stop to further expansion. The Greek community became defined in its extent and there began the process of heightened inner organization that attended the commercial activity necessary to providing for the growing population without further colonization. The Greek community became from within and without more and more a unit. Such a determination of the sea routes and the geography of the Mediterranean as followed from the commercial interrelations of the new Greek society was the proximate completion of the reconstruction of the objective world whose analysis brought forth the Ionian systems.

[30] The attitude of this reconstruction had been the recognition of the absence of limits. The old limits were gone and the generalized elements of past experience that filled the place of the old mythological world were activities that carried with themselves no inherent limits. The possibility of unending voyaging out from and around the central continent was the predominant feature of the consciousness of these men, until there arose the constructive content in the world which came with organized commercial relations. The Apeiron, the unlimited, was the necessary attribute of the world. The world as stimulus [to] speculation is necessarily unlimited but as a stimulus to an organized activity it must be a unit or the activity cannot be normal or successful. For Ionia there was not much possibility of further development. The Persians had crushed the spontaneous life [of] the Greek communities. Their dependence upon the [O]rient became a political and social one and the blighting influence of the east checked advance.

On the other hand in the west we find two movements that brought to consciousness the social individual. The national reaction against the 
Carthaginians reinforced the race consciousness and gave thus the individual the content of the national life while the growing commercial connection with the east organized his activity - made of the objective world a stimulus that called forth a unified act. He was shut off on the west[;] in the east he came into contact with a perfectly well known and definitely valued complex of communities. The political development under the enlightened [31] tyrannies of Acharna and Syracuse broke up the older tradition unconscious political bonds and those that were substituted represented the deliberate recognition of the meaning and value of the government to the individual and that of the individual to the government. It was from the west that reconstructed mythology of the nation went out, with the consciousness of its value for the whole Greek community and its adaptation to the demands of the socially organized Greek city. The comedy with its criticism of the older theology and of social relations sprang up in Sicily, and as we have seen it was from Sicily that the emancipated Greek individual went to the mother country - the Sophist [sic]. It was in Elia that the Phokaens settled after they had been driven from Asia Minor by the Persians and from their western colonial fields by the Carthaginians. They more than any other community had opened up to the Greeks an unlimited world in the west and they more than any other community had felt the insurmountable obstacles that hemmed in the Greeks from both sides. It was they therefore that would have the vivid consciousness of the limits that must govern their reaction upon the world. It was natural that Xenophanes[,] coming with the religious and aesthetic realization of the oneness of [the] world that marked as we have seen the downfall of the Ionian communities after their unlimited theoretical world had been forcibly hemmed in[,] should find in Elea appreciation and arouse [32] profounder speculation. For here an activity that had set no limits to itself had been violently crushed by forces that bound them on all sides. The most vivid feature of the common consciousness must have been negation of what had been an unchecked movement. In a word[,] the world that had invited them [to] more and more distant voyages now meant nothing but cessation and helpless recognition [of] the organization of the coasts of the Mediterranean that had broken the wings of their boundless adventure and left them only the homely activities of their quiet little city. They had been at [the] further eastern extremity of the Greek world and had built up colonies and $[\ldots]$ commerce in the far west beyond the rivalry of the most daring of the other Greek cities. They were in no position to enter into competition with the communities the channels of whose trade were all fixed and defended. The world on all sides possessed for them only stimuli to repression. Parmenides' system is but the generalization of this 
psychological attitude. While for Heraclitus feeling the unceasing disappearance of the old object in the new there was no unity except in the uniformity of this process[,] for Parmenides the new object disappeared completely in [the] whole which necessarily suppressed for the Eleans the very activity that the object as stimulus would have called forth.

Pythagoras brought with him on the contrary not only the social content of the popular religious movement in the Greek mother country and islands[,] but also the conception of an organized life that should deepen[,] develop and transfigure it. He had his followers so order the social relations that his larger [33] content which had become the common property of the whole Greek society should control their immediate individual actions. Pythagoreanism meant inner social organization. And Pythagoras also appealed to a sympathetic psychological attitude. In the cities of Greater Greece the problem of the relations of the individual and the whole community had become acute. It was not simply the contest of the mass of the small farmers and the trading class with the old traditional nobility [-] that stage had been gradually passed. It was the political individual and the whole of such individuals that must be brought into organic relations. We find a notable effort in this direction in the celebrated laws of Epidauros. They face an entirely different problem than do those of Solon. It is however impossible to organize social relation[s] except as the world of objects that[,] as stimuli call forth human activities[,] [are] all also organized. A sense of the harmonious interelation [sic] of the different parts of the world was but the objectification of the inner harmony that was sought. The naive assertion that external objects were number was the affirmation that they were in their very nature harmoniously interrelated. It is not necessary for the purpose of this paper to carry the analysis of the social conditions of the Greek world further. It is not [...] assumed of course that it has given in any sense an adequate account of these conditions. I have only sought to make evident that every philosophic system must represent the psychological attitude of the people of its time, and that it is impossible to do justice historically to it without reading it in term [...]

\section{Box 10, Folder 33}

[22] completely that it does not reach the point of bringing to consciousness the larger social meaning of the act. It is indeed with great difficulty that we can reproduce in our own feeling the network of ritualistic family and tribe relations that represented the entire social content of the activity of peoples in such a stage development. 
That which characterizes the period of Greek political history is the development of the conception of the citizen whose activity - political activity - is called forth not by the above described immediate social relations but by his capacity to [23] grasp the situation and offer rational advice with reference to it. It was in his capacity as rational citizen only that the Greek politician appeared before his fellow citizens to offer his counsel upon all and every subject that concerned the state.

The conception of the individual politically was in so far formed at this time that he was freed from his purely inherited social position and could discuss state matters not as [a] member simply of clan or family. The individual impulse to discuss, advise and direct was grasped as coincident with the general social impulse to follow the most rational course in state [24] matters. The Greek political consciousness had reached the point at which it recognized in each citizen no matter what his position might be within the inherited structure of the state, a rational being one open to reason and capable of expressing his own view. This conception of the rational being comes early in the Greek consciousness. Their whole history shows how near the surface it had been from the earliest times. In its abstract form [-] the form in which the Sophistrhetoricians first enunciated it [-] it was almost at once subject to the destructive criticism of Socrates and Plato. The practical assumption of the Greek political life was that rationality carried with it its own [25] control. It assumed indeed exactly that coincidence of the individual and the common interests the consciousness of which we have given as the expression of full individuality. Socrates and Plato's criticism was that the calling of the statesman was a trade that must be learned as well as that of the shoemaker or the pilot. The criticism was perfectly justified by Grecian history. The truth of the Greek democrat and Sophist lay like the truth of the abstract assumptions of the French revolutionists on the negative side. As against the narrow tribal ritualistic and family expressions of traditional Greek society the assumptions of the absolute [26] rationality of the Greek citizen was justified just as against the frightfully unjust and unjustified differences in rank of the old French state the assertion of the abstract equality of all men justified. The criticism of the Socratic philosophers did not destroy this element of truth it commenced the process of working out the positive value of that which had only a negative value. But these two phenomena are more than parallel phenomena. They are but the expression on two sides - the psychological and the political — of the same fact.

The psychological assertion is as abstract as the political. It [...] 
406 (c) Canadian Journal of Sociology/Cahiers Canadiens de Sociologie 38(3) 2013 